This is an Accepted Manuscript of an article published by Taylor \& Francis in Asian Studies Review on 3 April 2015, available online:

http://www.tandfonline.com/doi/full/10.1080/10357823.2015.1024099

\title{
Realising Rights in Low Quality Democracies: Instructive Asian Cases
}

\author{
ANDREW ROSSER* \\ University of Adelaide
}

\begin{abstract}
Do justiciable legal frameworks for the protection of human rights (JLFPHR) promote the realisation of human rights in countries with low quality democracies? If so, under what conditions? And what do answers to these questions imply for activists' strategies for promoting human rights? This essay considers these questions drawing on the papers published here on Indonesia, Nepal, Malaysia and Timor Leste. It suggests that while rights agendas encounter serious political, social and institutional obstacles in low quality democracies, JLFPHR make a positive contribution to rights realisation by: (i) aiding political mobilisation by poor and marginalised groups and their supporters in the NGO movement and (ii) providing a legal basis for these groups to challenge rights breaches through the courts, at least where viable legal pathways for such efforts exist and these groups can muster the financial, organisational and technical resources required to launch and sustain court cases. In terms of strategy, the paper thus suggests that, in addition to constructing JLFPHR, rights activists should focus on facilitating political mobilisation around rights issues, constructing legal pathways that are likely to be receptive to rights causes, and creating support structures to enable citizens to exploit these pathways.
\end{abstract}

Keywords: law, politics, human rights, justiciability, democracy, Indonesia, Timor Leste, Nepal, Malaysia

*Correspondence Address: andrew.rosser@adelaide.edu.au 
This is an Accepted Manuscript of an article published by Taylor \& Francis in Asian Studies Review on 3 April 2015, available online:

http://www.tandfonline.com/doi/full/10.1080/10357823.2015.1024099

\section{Introduction}

Recent decades have seen many developing countries enshrine human rights in national constitutions and laws. So marked has this change been that, according to one group of scholars, a written constitution with a bill of fundamental rights protected by a judiciary with powers of judicial review is now "seen as a global model of democratisation or ... part of the 'script of modernity like presidencies and legislatures"' (Keith et al., 2009, p. 646, quoting Ginsburg, 2003, p. 26). At the same time, an increased number of developing countries have ratified international human rights treaties such as the International Covenant on Civil and Political Rights (ICCPR), the International Covenant on Economic, Social and Cultural Rights (ICESCR) and the Convention on the Elimination of All Forms of Discrimination Against Women (CEDAW), all of which are potentially justiciable at the domestic level once ratified.

In parallel with these developments, international donor organisations have increasingly embraced rights-based approaches to development (RBAs). The United Nations Development Programme (UNDP), for instance, is now formally "committed to a human rights-based approach in its programming, guided by international human rights standards and principles" (UNDP, 2006, p. 46), while the International Labour Organization (ILO) generally couches its programs in terms of a concern to promote collective social, economic and child rights (Grugel and Piper, 2009, pp. 83-84). Other official donors such as the World Bank, DFID, SIDA and AusAID (now DFAT) have also shown growing interest in RBAs (Eyben, 2003; World Bank, 1998; Smith and McMullan, 2009), while major international NGOs such as Oxfam, ActionAID, Amnesty International and Human Rights Watch have become their strongest proponents. 
This is an Accepted Manuscript of an article published by Taylor \& Francis in Asian Studies Review on 3 April 2015, available online:

http://www.tandfonline.com/doi/full/10.1080/10357823.2015.1024099

Underlying these developments has been a widespread belief that justiciable legal frameworks for the protection of human rights (JLFPHR) such as international treaties, national constitutions and laws are an effective mechanism for promoting human rights in developing countries (Crook, 2001). As Keith et al. (2009, p. 645) have noted, the trend towards constitutionalisation of human rights and ratification of international human rights treaties is founded on a belief that governments will be "less willing to abuse rights that are clearly and publicly promised to their citizens in a legally binding document and that are supported by constitutional mechanisms, such as an independent judiciary". Likewise, Irene Khan (2009, p. 203), the former head of Amnesty International, has noted that the law "can be a tremendous force for protecting the rights of those living in poverty" providing both "a shield against the kinds of harm that cause or perpetuate poverty" and "a weapon for helping people increase their freedom”.

Is this faith in the transformative potential of JLFPHR justified? Gauri and Brinks (2008a, p. 15) have suggested that JLFPHR are much more likely to contribute to the realisation of human rights in countries that have "high quality" democracies because a "high quality, multiparty democracy both facilitates the creation of an independent judiciary with powers of judicial review, and makes it less likely that legislative policymakers will easily coordinate to override or stifle judicial intervention". Both of these factors, they argue, facilitate legal strategies for the promotion of human rights while political competition between parties facilitates political strategies. But what about countries with low quality democracies? Can JLFPHR make a significant positive difference with regards to legal and political strategies in these countries as well? Or does low quality democracy make change impossible? One possible implication of Gauri and Brinks' view is that rights activists and donors should concentrate their efforts to promote human rights on countries that have high quality democracies. Would this be the right approach? 
This is an Accepted Manuscript of an article published by Taylor \& Francis in Asian Studies Review on 3 April 2015, available online:

http://www.tandfonline.com/doi/full/10.1080/10357823.2015.1024099

The papers in this special issue aim to provide answers to these questions. All of the countries examined here (Nepal, Malaysia, Indonesia and Timor Leste) have recently established JLFPHR by introducing new national Constitutions and laws that protect human rights, making changes to existing Constitutions or laws that do the same, and/or ratifying international human rights treaties. At the same time, they are all characterised by low quality democracy - in particular, weak party systems, incipient or disorganised civil societies, high levels of corruption, and weak and inefficient court systems - reflecting recent histories of authoritarian colonial (Timor Leste), monarchical (Nepal) or single party (Indonesia) rule or, in Malaysia's case, continued single party rule. As Table 1 illustrates, these countries were all rated as "partly free" by Freedom House between 2000 and 2013 with the exception of Indonesia, which graduated to "free" status in 2006 - ratings that stand in contrast to those for the high quality democracies that have so far been the focus of the literature on the impact of JLFPHR: the United States, Canada, Britain, South Africa, Brazil, Costa Rica and India (Scheingold, 1974; Rosenberg, 1991; McCann, 1994; Epp, 1996; 1998; Vanhala, 2011; Baxi, 1985; Joshi and Moore, 2000; Cornwall et al., 2006; Gauri and Brinks, 2008b; Gargarella et al., 2009; Joshi, 2010; Wilson, 2011; Yamin and Gloppen, 2011). As a group, these countries thus constitute a useful set of cases for assessing whether JLFPHR can work in low quality democracies; if so, in what ways; and the implications for rights-oriented strategies in these contexts.

\section{INSERT TABLE 1 ABOUT HERE}

In broad terms, the papers raise doubts about the notion - implicit in Gauri and Brinks' statement above - that JLFPHR contribute little to the realisation of human rights in countries with low quality democracies. Although the papers show that rights agendas encounter 
This is an Accepted Manuscript of an article published by Taylor \& Francis in Asian Studies Review on 3 April 2015, available online:

http://www.tandfonline.com/doi/full/10.1080/10357823.2015.1024099

serious political, social and institutional obstacles in these countries, they also suggest that JLFPHR contribute to rights realisation in two ways: by (i) aiding political mobilisation by poor and marginalised groups and their supporters in the NGO movement; and (ii) providing a legal basis for these groups to challenge rights breaches through the courts, at least where viable legal pathways for such efforts exist and these groups can muster the financial, organisational and technical resources required to launch and sustain court cases. In policy terms, the paper thus suggests that rights advocates should seek not only to establish JLFPHR in low quality democracies but also to enhance their impact by facilitating effective political mobilisation around rights issues, promoting legal reforms that create legal pathways receptive to rights causes, and promoting the development of SSLMs (support structures for legal mobilisation) that help poor and marginalised groups exploit these pathways.

In presenting this argument, I begin by reviewing the nature of the debate so far about the effects of JLFPHR on rights realisation. While this debate has focused overwhelmingly on high quality rather than low quality democracies, it is necessary to review it because it provides the conceptual context for the arguments advanced in this introductory article and in the individual papers that make up the special edition. I then summarise the findings of the papers published here. In the final part of the paper, I consider the policy implications of the analysis.

\section{The Debate So Far}

Analysis of the impact of JLFPHR on rights realisation has yielded three main perspectives. The first of these - which is associated in particular with scholarship on "law and social movements" - has suggested that JLFPHR contribute little to the realisation of human rights through the court system but do so to some extent outside it. Courts, it is argued, are not 
This is an Accepted Manuscript of an article published by Taylor \& Francis in Asian Studies Review on 3 April 2015, available online:

http://www.tandfonline.com/doi/full/10.1080/10357823.2015.1024099

impartial arbiters of the law; rather, they are politically aligned, because of either the ideological and political affiliations of their judges or - particularly in developing countries their vulnerability to corruption and political interference. With a judiciary that is unsympathetic towards human rights or easily persuaded to oppose them, any effort by poor and marginalised people to seek justice through the court system is thus bound to fail even if the latter have a watertight case in legal terms. At the same time, however, scholars working in this vein argue that the notion that people have legally enforceable rights - what Scheingold (1974) has called the "myth of rights" - can be a useful spur to political mobilization, while others have suggested that litigation can assist the development and consolidation of social movements and provide a normative framework to inform political activities (McCann, 1994; Silverstein, 2003, p. 413). In terms of strategy, the implication is that rights activists should desist from pursuing matters through courts and focus instead on the political arena where there is perceived to be greater potential for progress. Such views have been expressed most prominently in relation to civil rights struggles in the US (Scheingold, 1974; Rosenberg, 1991; McCann, 1994) but have also featured in scholarly work on India - for instance, Joshi's (2010) work on Maharashtra's Employment Guarantee Scheme and Menon's (2004) work on abortion, rape and female representation in the Indian parliament.

A second perspective has emerged out of Epp's (1996; 1998) analysis of "rights revolutions"1 in the US, Canada, Britain and India. The starting point for Epp's analysis is recognition that JLFPHR are not "self-activating" in the sense that, while they "create legal interests (rights), they create no corresponding institutional resources to actualize those interests” (Epp, 1996, p. 766). Consequently, JLFPHR can only be enforced when potential litigants are able to mobilise the resources required to access and utilise the court system. Epp (1998) suggests that three types of resources - which he defines as collectively constituting 
This is an Accepted Manuscript of an article published by Taylor \& Francis in Asian Studies Review on 3 April 2015, available online:

http://www.tandfonline.com/doi/full/10.1080/10357823.2015.1024099

the "support structure for legal mobilisation" (SSLM) - are particularly important in this respect: (i) organised group support (that is, the presence of "repeat players" who have extensive experience in using the court system), (ii) financing (including from private sources but especially from government sources), and (iii) the structure of the legal profession (by which he means in particular its ethnic diversity and the scale of legal firms, both of which potentially influence prospective litigants' ability to find a lawyer willing to pursue a human rights-related court case). In contrast to the negative view of court processes presented by law and social movement scholars, then, Epp suggests that the realisation of rights through the courts is contingent upon prospective litigants' ability to mobilise these various resources. In terms of strategy, this perspective emphasises the need to ensure that citizens have access to well-funded state-provided legal aid programs and/or other organisations that provide legal assistance.

Subsequent work has questioned whether Epp's ideas are universally applicable. For instance, Wilson $(2009$; 2011) has argued that "rights revolutions" in Costa Rica and Columbia over the past two decades stemmed from the fact that Superior Courts in these countries abandoned high levels of judicial formality, adopted broad definitions of standing, removed barriers to access, and resolved cases quickly, thereby making it possible for poor and marginalised groups to access and utilise the court system successfully to promote their rights without the support of SSLMs (see also Conant, 2006; Wilson and Cordero, 2006). Rather than promoting the development of SSLMs, he suggests, rights advocates should focus on constructing court systems that maximise their accessibility to the poor and marginalised. Similarly, Brinks and Gauri (2008, p. 310) have suggested that SSLMs may matter more in some sectors than in others. For instance, they have noted that the successful enforcement through the courts of health-related rights in Brazil has depended not on "the coordinated action of civil rights advocacy organisations" (as per the SSLM model) but rather 
This is an Accepted Manuscript of an article published by Taylor \& Francis in Asian Studies Review on 3 April 2015, available online:

http://www.tandfonline.com/doi/full/10.1080/10357823.2015.1024099

"the accumulation of many individual actions on the part of middle and lower class claimants, who have been availing themselves of individual public and private lawyers in an uncoordinated, unorganised way". At the same time, they note that SSLM may be a necessary precondition for successful judicial enforcement of education rights because greater demandside coordination among a large number of applicants is required, reflecting the fact that education is delivered on a group rather than one-to-one basis. As such, they imply that efforts to promote SSLM should be carried out selectively, focusing on some sectors more than others.

Neither of these critiques, however, entails a complete rejection of Epp's ideas. They merely suggest that the role of SSLMs is likely to be greater in contexts where courts are relatively costly and/or coordination is required among groups of people in order to launch legal action.

A third group of scholars has pointed to judicial activism as a key determinant of whether or not JLFPHR have a positive effect on the realisation of human rights. Judges, they have suggested, have considerable scope for autonomous decision-making, at least in court systems characterised by structural independence from the executive and legislature, notwithstanding their formal roles as interpreters rather than makers of the law. At the same time, they subscribe to particular ideological and political causes including the welfare of their respective courts and, in some cases, are willing to engage in judicial activism - that is, deliver court verdicts that favour these causes even if this means breaching some sense of legal appropriateness. Finally, they are capable of acting strategically - that is, in a manner that minimises the risk that their decisions will attract a political backlash, in particular from other arms of government concerned about usurpation of their authority. Accordingly, this perspective suggests that JLFPHR are most likely to translate into rights-friendly court decisions when a majority of judges in a court are sympathetic towards the protection of 
This is an Accepted Manuscript of an article published by Taylor \& Francis in Asian Studies Review on 3 April 2015, available online:

http://www.tandfonline.com/doi/full/10.1080/10357823.2015.1024099

human rights or believe that protecting rights will benefit their court in some way (e.g. by enhancing its legitimacy), are willing to deliver verdicts that challenge prevailing legal norms, and determine that they can do so without triggering a severe political backlash against themselves or their court. By contrast, where these conditions are not in place, court decisions will not favour human rights.

In this vein, Baxi (1985), for instance, has suggested that "social action litigation" (SAL) in India during the late 1970s and early 1980s occurred because of efforts by the Indian judiciary to ameliorate the misery of the masses, restore the image of the court following the 1975-76 Emergency, and establish a new base of legitimacy for judicial authority (see also Bhagwati, 1984; Cassels, 1989). Similarly, drawing on a range of country case studies from the developing world, Brinks and Gauri (2008, p. 320) have described judges as "qualified strategic actors" - that is, strategic actors who are "willing to issue challenging decisions", but "not ordinarily issue doomed ones, no matter what the law might seem to require". The role of judicial activism has also been emphasised in several analyses of the role of courts in rights realisation in developed countries (see Kmiec, 2004; King, 2012).

To the extent that scholars have examined the effect of JLFPHR in low quality democracies, they have generally suggested that these frameworks have had very little impact on rights realisation because of limited state - in particular judicial - responsiveness to citizens' demands and/or barriers to citizen legal and political mobilisation. In their analysis of the Angolan case, for instance, Skaar and Van Dúnem (2006) argue that formal Constitutional protection of social rights has done little to aid their realisation in practice because Angolan courts have lacked the human, technical and financial resources to function properly and citizens have lacked the legal know-how, financial resources and confidence to take legal action when they are accessible and functional. Echoing Epp, they draw particular 
This is an Accepted Manuscript of an article published by Taylor \& Francis in Asian Studies Review on 3 April 2015, available online:

http://www.tandfonline.com/doi/full/10.1080/10357823.2015.1024099

attention to the undersupply of legal aid services in the country, something that would help address constraints on poor people's ability to mobilise for legal action. In some low quality democracies, activist judges have nevertheless occasionally delivered decisions that favour protection of human rights (see, for instance, Bourchier, 1999 and Butt, 2006 on courts in Indonesia), but more commonly, political subordination of courts has made judges timid and conservative. Commenting on the failure of Nigeria's courts to promote realisation of education and health rights in that country, Odinkalu (2008, p. 218), for instance, argues that "the judiciary has disabled itself from intervening through a combination of judicial timidity and self-imposed constraints". Many cases simply do not make it to court. And when they do, judicial timidity often stands in the way of court decisions that serve to promote rights-related causes.

In sum, then, there is broad agreement among scholars that JLFPHR have a positive effect on the realisation of human rights in relatively high quality democracies. However, there is debate about why this is the case. On the one hand, some scholars have suggested that rights realisation in these countries has come about mainly because of political mobilisation (that is, the pursuit of human rights causes through political mechanisms such as lobbying, protest and shaping public opinion) rather than legal mobilisation (that is, the pursuit of these causes through legal mechanisms such as courts). On the other hand, those who see legal mobilisation as having played an important role in promoting rights realisation have given different emphases to the roles of SSLMs, judicial activism and the nature of court design. To the extent that scholars have examined the effects of JLFPHR in low quality democracies, they have tended to emphasise the obstacles to rights realisation stemming from low state, especially judicial, responsiveness to citizen demands and barriers to citizen legal and political mobilisation. 
This is an Accepted Manuscript of an article published by Taylor \& Francis in Asian Studies Review on 3 April 2015, available online:

http://www.tandfonline.com/doi/full/10.1080/10357823.2015.1024099

\section{Law and the Realisation of Human Rights in Low Quality Democracies}

The papers published in this special edition reaffirm the finding of studies such as Skaar and Van Dúnem (2006) and Odinkalu (2008) that rights agendas run up against a range of significant political, social and institutional obstacles in low quality democracies. For instance, in her paper on the Malaysian women's rights organisation, EMPOWER, Juanita Elias (2015) argues that this organisation has had limited success in promoting the rights of informal sector workers, refugees and sexual minorities in the face of rising Islamic conservatism, a patriarchal society and a development model that emphasises the exploitation of cheap and flexible labour, notwithstanding the Malaysian government's ratification of CEDAW in 1995. Margaret Becker's (2015) paper on two women's rights NGOs in Nepal and Jayne Curnow's (2015) on religious courts in Indonesia also suggest that patriarchal power structures and cultural norms impede women's efforts to claim their rights. Laura Grenfell's (2015) analysis of Timor Leste's Constitution and legal system suggests that flaws in the design of Constitutions can limit the range of legal pathways through which citizens and activists are able to assert their rights. Finally, my paper on education rights in Indonesia (Rosser, 2015) illustrates the obstacles to rights realisation caused by pervasive judicial corruption and a broad structure of power and interest dominated by predatory elites who have little interest in human rights. In general, the papers portray judiciaries as politically timid and/or lacking in capacity and resources and ordinary citizens and rights activists as facing a range of obstacles to engaging in legal and political mobilisation.

At the same time, however, the papers also challenge the notion that JLFPHR are unlikely to have much of an impact on the realisation of rights in countries with low quality democracies. Specifically, they suggest that JLFPHR contribute to rights realisation in two ways. 
This is an Accepted Manuscript of an article published by Taylor \& Francis in Asian Studies Review on 3 April 2015, available online:

http://www.tandfonline.com/doi/full/10.1080/10357823.2015.1024099

\section{JLFPHR and legal mobilisation}

First, the papers suggest that JLFPHR can aid successful legal mobilisation by citizens in such countries as long as two conditions are met: (i) there are specific legal pathways that offer some prospect of victory for rights causes; and (ii) citizens can mobilise the financial, technical and organisational resources required to launch and sustain these cases - in other words, they have access to a SSLM.

In their papers on the Indonesian case, Rosser (2015) and Curnow (2015) show that Indonesian citizens have in recent years successfully pursued redress for rights abuses or challenged government policies and practices that infringe rights by making use of courts with activist judges established following the fall of Suharto's authoritarian New Order regime in the late $1990 \mathrm{~s}$ - itinerant religious courts in the case of the Indonesian widows/divorcees examined by Curnow and the Constitutional Court in the case of the parents and students examined by Rosser. Rosser shows that parents and students have also taken advantage of the increased potential for judicial activism within regular courts generated by democratisation. Indonesia's judiciary has in general remained characterised by corruption and non-receptiveness to rights causes despite political reform. At the same time, the physical concentration of courts in urban areas, the high cost of legal advice and court processes, and limited legal know-how among ordinary citizens mean that few rights-related cases make it to court in the first place. Nevertheless, Curnow and Rosser show that some individuals have been able to strategically exploit new openings within the court system to defend and enhance their rights.

By contrast, in Timor Leste where, as Grenfell (2015) explains, such openings do not exist, citizens have had much less success in promoting rights-related causes through the 
This is an Accepted Manuscript of an article published by Taylor \& Francis in Asian Studies Review on 3 April 2015, available online:

http://www.tandfonline.com/doi/full/10.1080/10357823.2015.1024099

court system. Rather they have had to seek other points of access to the state such as direct appeals to the President. Grenfell notes several specific problems with Timor's courts: low technical capacity within the judiciary, an inability to resolve cases quickly, and politicisation of the judiciary.

Viewed alongside Skaar and Van Dúnem’s (2006) analysis of Angola and Odinkalu’s (2008) analysis of Nigeria, these papers suggest that low quality democracies are not all of a piece in terms of the extent to which judiciaries are responsive to citizens' demands regarding rights. While low quality democracies seem in general to have court systems that are unreceptive to rights-related causes, some offer specific legal pathways that offer some prospect of victory for these causes when citizens can mobilise to access them. In this respect, these cases also indicate a need to disaggregate national court systems into distinct sets of pathways, some of which are more receptive to rights-related causes than others, rather than seeing them as monolithic wholes.

Rosser and Curnow's analyses also suggest that individuals' successes in promoting rights through courts have been predicated upon the support of NGOs with the resources to launch and sustain court cases. In both cases, they argue, it is difficult to imagine individuals successfully pursuing their rights in court without the financial, organisational and technical assistance provided by NGOs such as LBH Jakarta, PEKKA and Indonesia Corruption Watch. In an earlier paper, Rosser and Curnow (2014) argued that NGOs played a crucial role in supporting efforts by parents to challenge through the Constitutional Court Indonesian government policy on so-called "international standard schools". The papers published here provide further evidence that successful citizen efforts to defend rights contained in JLFPHR in Indonesia have only occurred when citizens have had access to an effective SSLM that has enabled them to mobilise the resources required to launch and sustain expensive and timeconsuming court cases. 
This is an Accepted Manuscript of an article published by Taylor \& Francis in Asian Studies Review on 3 April 2015, available online:

http://www.tandfonline.com/doi/full/10.1080/10357823.2015.1024099

The essential role of NGOs in creating SSLMs for poor and marginalised citizens is also a strong theme of Becker's (2015) analysis of two women's organisations in Nepal. She argues that assistance from Women for Human Rights (WHR), an NGO established to challenge discrimination against Nepalese widows, has been a crucial precondition for their efforts to use courts to assert their rights. By comparing the strategies and methods used by WHR with those of another NGO less active in the legal realm, Sangam, she also shows that the emergence of SSLMs cannot be taken for granted: the ability of an NGO to construct an SSLM for poor and marginalised groups is founded on access to elite networks, educated leadership and international support - resources that are all in limited supply in the NGO sector.

In terms of the debate between Epp, Wilson, and Gauri and Brinks regarding SSLMs, these papers - along with Grenfell's and Elias' papers on Timor Leste and Malaysia respectively - thus suggest that the role of SSLMs in low quality democracies hinges on two factors. The first is whether or not there is demand for their emergence. Grenfell (2015) and Elias (2015) suggest that demand for SSLMs will be low where poor Constitutional Court design and state repression limit the effectiveness of legal strategies for pursuing rights. By contrast, Rosser's (2015) and Curnow's (2015) analyses of the Indonesian case suggest that there will be demand for SSLMs where there are openings within a country's court system that provide some prospect of victory for rights-related causes. The second factor relates to the supply of SSLMs. Becker (2015) indicates that SSLMs do not appear as if by magic simply because there is demand for them but require access to resources that are not universally or easily available. Whether SSLMs have a key role to play in promoting human rights in low quality democracies is thus conditional - first, upon the existence of legal mechanisms that can be exploited successfully to promote rights and, second, upon the 
This is an Accepted Manuscript of an article published by Taylor \& Francis in Asian Studies Review on 3 April 2015, available online:

http://www.tandfonline.com/doi/full/10.1080/10357823.2015.1024099

existence of resources and networks including both domestic and foreign support that enable their establishment and operation.

\section{JLFPHR and political mobilisation}

The papers published here suggest that JLFPHR also make a positive difference in low quality democracies by aiding political mobilisation by poor and marginalised groups and their supporters in the NGO movement. While the broader political climate may be less conducive to political mobilisation around rights issues in low quality than in high quality democracies, the papers suggest that JLFPHR nevertheless provide a means for citizens and NGO activists in the former countries to highlight and challenge government mistreatment and persecution of poor and marginalised groups, promote alternative visions of development, mobilise people in support of particular causes, and engage in lobbying for policy change. In particular, such frameworks provide a means by which these actors can challenge some of the worst effects of neoliberal developmentalism. ${ }^{2}$ As several scholars have pointed out, neoliberalism and RBAs imply quite different approaches to policy, particularly with regards to the role of the state in the economy and the social sectors (Gauri, 2004; Sklair, 2002; O'Connell, 2007). The papers show that JLFPHR have been important reference points for citizens and activists in their efforts to challenge neoliberal development policies, in particular with regards to the position of women in society (the focus of most of the papers) and access to education (the focus of Rosser's paper on Indonesia). They suggest that JLFPHR are also useful in challenging conservative social attitudes that contribute to injustices.

Elias (2015), for instance, argues that CEDAW has become "part of a locally situated politics of gender justice in Malaysia - one in which human rights for women are continually 
This is an Accepted Manuscript of an article published by Taylor \& Francis in Asian Studies Review on 3 April 2015, available online:

http://www.tandfonline.com/doi/full/10.1080/10357823.2015.1024099

being reshaped and rethought in relation to the everyday lived experiences of women in Malaysia". As the basis for EMPOWER's efforts to "challenge the very classed, gendered, racialised and nationalistic assumptions that are embedded in [Malaysia's] national rights regimes," she suggests, CEDAW has helped to initiate a different sort of "rights revolution" from that examined by Epp - namely, one involving a shift in people's consciousness about what rights mean and who is entitled to them. Elias suggests that this revolution is still far from complete but EMPOWER is nevertheless pushing in that direction. Similarly, Becker (2015) shows that rights talk has become a useful device for encouraging women to challenge social mores that place women in subordinate/compliant roles, in particular Nepalese notions of what it means to be a "good woman".

In some cases, the papers suggest, these efforts can lead to improvements in government policies and practices, particularly where they gain media attention and influence public opinion, as well as simply raising people's consciousness of their rights and helping to maintain struggles against inequality. Rosser (2015), for instance, notes the important role political mobilisation played in achieving reform in relation to two key education issues in Indonesia - the national exam and the legal status of educational institutions - policies both inspired by the neoliberal education agenda. Similarly, Becker (2015) suggests that WHR's activism in relation to widows' rights has raised the public profile of widows' rights, changed development discourse on the subject, slowly changed attitudes and beliefs within society, and contributed to broader policy reform.

In this respect, the papers have some resonance with arguments by law and social movements scholars that political mobilisation rather than legal mobilisation is the most effective way of promoting rights causes. In contrast to these scholars, they indicate that political and legal mobilisation are not necessarily mutually exclusive strategies for citizens and rights activists but, rather, can work hand in hand to promote change. Becker (2015), for 
This is an Accepted Manuscript of an article published by Taylor \& Francis in Asian Studies Review on 3 April 2015, available online:

http://www.tandfonline.com/doi/full/10.1080/10357823.2015.1024099

instance, notes that WHR employs both legal and political mobilisation to achieve its objectives, while Rosser (2015) and Curnow (2015) note that education and women's activists in Indonesia have engaged in political and legal mobilisation simultaneously, with political mobilisation assisting legal strategies by increasing pressure on courts to find in favour of rights. For this reason, it arguably makes more sense to talk in these contexts about support structures for political and legal mobilisation (SSPLM) rather than SSLM, given that the NGOs at the core of SSLMs often do not simply support legal mobilisation by poor and marginalised groups but also their political mobilisation.

\section{Conclusion}

This paper has examined whether JLFPHR serve to promote the realisation of human rights in low quality democracies, drawing on the findings of the papers published here. As noted, Gauri and Brinks have suggested that JLFPHR are unlikely to have a substantial positive impact in such countries because they typically lack independent judiciaries with powers of judicial review and there is a potential for legislative policymakers to coordinate to override or stifle judicial intervention. It is argued here, by contrast, that while rights agendas encounter serious political, social and institutional obstacles in low quality democracies, JLFPHR aid the realisation of human rights in two ways: 1) by facilitating political mobilisation by poor and marginalised groups and their supporters in the NGO movement and 2) enabling these groups to use the court system to pursue redress for rights breaches and challenge government policies and practices that infringe rights, at least where viable legal pathways exist and these groups can muster the financial, organisational and technical resources required to launch and sustain court cases. The serious political, social and institutional obstacles to promoting rights causes in developing countries mean that many 
This is an Accepted Manuscript of an article published by Taylor \& Francis in Asian Studies Review on 3 April 2015, available online:

http://www.tandfonline.com/doi/full/10.1080/10357823.2015.1024099

rights-related cases never make it to court in the first place or receive a hearing in political fora such as parliaments or the media. Nevertheless, in these two ways, JLFPHR can make a positive difference.

What are the implications of this argument for policy/strategy? First and foremost, it suggests that efforts to create JLFPHR in low quality democracies are a worthwhile endeavour, even if the potential for rights realisation in these countries is lower in the short term than in high quality democracies. On the basis of Gauri and Brinks' analysis, one could conclude that efforts to construct JLFPHR should be focused on high quality democracies. However, such an approach would eliminate the real benefits that JLFPHR produce in low quality democracies. Grugel and Piper (2009) have questioned whether a focus on rights is the best option for citizens and activists seeking to challenge inequality, discrimination and marginalisation, asserting that the promotion of rights is constrained by globally dominant liberalism. Yet our papers suggest that JLFPHR can be a useful resource for efforts to challenge (neo-)liberal policies and promote alternative visions of development, sometimes effectively. As de Sousa Santos and Rodriguez-Garavito (2005, p. 2) have noted, globalisation has not simply entailed "top-down processes of diffusion of economic and legal models from the global North to the global South" but also "growing grassroots contestation of the spread of neoliberal institutions" often through legal mechanisms (see also Rajagopal, 2012). The papers here suggest that JLFPHR can assist grassroots actors and their NGO supporters in mobilising the law as part of these struggles even in the context of weak court systems and unresponsive political institutions.

Second, our papers suggest that where JLFPHR exist rights advocates should focus their efforts in low quality democracies in three areas: facilitating effective political mobilisation around rights issues, promoting legal reforms that create legal pathways receptive to rights causes, and promoting the development of SSLMs that help poor and 
This is an Accepted Manuscript of an article published by Taylor \& Francis in Asian Studies Review on 3 April 2015, available online:

http://www.tandfonline.com/doi/full/10.1080/10357823.2015.1024099

marginalised groups to exploit these pathways. Much of the literature on the effects of JLFPHR suggests that one or other of these elements should have strategic priority: for instance, political mobilisation in the case of scholars working in the law and social movements tradition and the creation of SSLMs in the case of Epp and his acolytes. However, the papers here suggest that rights advocates should pursue a more comprehensive and integrated agenda aimed at addressing the multiple barriers that rights-related causes face in countries with low quality democracies.

Such an agenda is, of course, ambitious and will not be realised easily. However, the fact that NGOs such as WHR in Nepal and PEKKA, Indonesia Corruption Watch and LBH Jakarta in Indonesia play a crucial role in supporting both political and legal mobilisation by poor and marginalised groups means that at least some concentration of effort is possible: support to these organisations would contribute to two channels of progress simultaneously. While the creation of effective legal pathways for rights realisation is crucial, it is arguably these organisations whose agency, whether via courts or political mechanisms, holds the key to overcoming the widespread breaches of human rights that occur in these countries. One hopes that they will succeed in their struggles.

\section{Acknowledgments}

I wish to thank Kanishka Jayasuriya, Juanita Elias and two anonymous reviewers for their comments on an earlier draft of this paper. The Australian Research Council funded the research on which this paper is based through grant number FT110100078. The usual caveat applies. 
This is an Accepted Manuscript of an article published by Taylor \& Francis in Asian Studies Review on 3 April 2015, available online:

http://www.tandfonline.com/doi/full/10.1080/10357823.2015.1024099

\section{References}

Baxi, Upendra (1985) Taking suffering seriously: Social action litigation in the Supreme Court of India. Third World Legal Studies 4, pp. 107-32.

Becker, Margaret, 2015. Constructing SSLM: Insights from struggles over women's rights in Nepal. Asian Studies Review 39(2), pp.

Bhagwati, P.N. (1984) Judicial activism and public interest litigation. Columbia Journal of Transnational Law 23, pp. 561-77.

Bourchier, David (1999) Magic memos, collusion and judges with attitude: Notes on the politics of law in contemporary Indonesia, in Kanishka Jayasuriya (ed.), Law, capitalism and power in Asia: The rule of law and legal institutions, pp. 233-52 (London: Routledge).

Brinks, Daniel and Varun Gauri (2008) A new policy landscape: Legalizing social and economic rights in the developing world, in Varun Gauri and Daniel Brinks (eds), Courting social justice: Judicial enforcement of social and economic rights in the developing world, pp. 303-52 (Cambridge: Cambridge University Press).

Butt, Simon (2006) Zealous reformers. Inside Indonesia 87. Available at http://www.insideindonesia.org/zealous-reformers, accessed 25 February 2015 [more details?] 
This is an Accepted Manuscript of an article published by Taylor \& Francis in Asian Studies Review on 3 April 2015, available online:

http://www.tandfonline.com/doi/full/10.1080/10357823.2015.1024099

Cassels, Jamie (1989) Judicial activism and public interest litigation in India: Attempting the impossible? The American Journal of Comparative Law 37(3), pp. 495-519.

Conant, Lisa (2006) Individuals, courts, and the development of European social rights. Comparative Political Studies 39(1), pp. 76-100.

Cornwall, Andrea, Silvia Cordeiro and Nelson Delgado (2006) Rights to health and struggles for accountability in a Brazilian municipal health council, in Peter Newell and Joanna Wheeler (eds), Rights, resources and the politics of accountability, pp. 144-62 (London: Zed).

Crook, Richard (2001) Editorial introduction. IDS Bulletin 32(1), pp. 1-7.

Curnow, Jayne (2015) Legal support structures and the realisation of Muslim women's rights in Indonesia. Asian Studies Review 39(2), pp.

de Sousa Santos, Boaventura and Cesar A. Rodriguez-Garavito (2005) Law, politics, and the subaltern in counter-hegemonic globalization, in Boaventura de Sousa Santos and Cesar A. Rodriguez-Garavito (eds), Law and globalization from below, pp. 1-26 (Cambridge: Cambridge University Press).

Elias, Juanita (2015) The challenges of realising women's human rights in Malaysia: The EMPOWER Women's Human Rights Report. Asian Studies Review 39(2), pp. 
This is an Accepted Manuscript of an article published by Taylor \& Francis in Asian Studies Review on 3 April 2015, available online:

http://www.tandfonline.com/doi/full/10.1080/10357823.2015.1024099

Epp, Charles (1996) Do Bills of Rights matter? The Canadian Charter of Rights and Freedoms. American Political Science Review 90(4), pp. 765-79.

Epp, Charles (1998) The rights revolution: Lawyers, activists, and supreme courts in comparative perspective (Chicago: University of Chicago Press).

Eyben, Rosalind (2003) The rise of rights. IDS Policy Briefing 17.

Gargarella, Robert, Pilar Domingo and Theunis Roux, eds. (2009) Courts and social transformation in new democracies: An institutional voice for the poor? (Aldershot: Ashgate).

Gauri, Varun (2004) Social rights and economics: Claims to health care and education in developing countries. World Development 32(3), pp. 465-77.

Gauri, Varun and Daniel Brinks (2008a) Introduction: The elements of legalization and the triangular shape of social and economic rights, in Varun Gauri and Daniel Brinks (eds), Courting social justice: Judicial enforcement of social and economic rights in the developing world, pp. 1-37 (Cambridge: Cambridge University Press).

Gauri, Varun and Daniel Brinks, eds. (2008b) Courting social justice: Judicial enforcement of social and economic rights in the developing world (Cambridge: Cambridge University Press). 
This is an Accepted Manuscript of an article published by Taylor \& Francis in Asian Studies Review on 3 April 2015, available online:

http://www.tandfonline.com/doi/full/10.1080/10357823.2015.1024099

Ginsburg, Tom (2003) Judicial review in new democracies: Constitutional courts in Asian countries (Cambridge: Cambridge University Press).

Grenfell, Laura (2015) Realising human rights in Timor Leste. Asian Studies Review 39(2), pp.

Grugel, Jean and Nicola Piper (2009) Do rights promote development? Global Social Policy 9(1), pp. 79-98.

Joshi, Anuradha (2010) Do rights work? Law, activism, and the Employment Guarantee Scheme. World Development 38(4), pp. 620-30.

Joshi, Anuradha and Mick Moore (2000) Enabling environments: Do anti-poverty programs mobilise the poor? Journal of Development Studies 37(1), pp. 25-56.

Keith, Linda, C. Neal Tate and Steven Poe (2009) Is the law a mere parchment barrier to human rights abuse? The Journal of Politics 71(2), pp. 644-60.

Khan, Irene (2009) The unheard truth: Poverty and human rights (New York: W.W. Norton and Co).

King, Jeff (2012) Judging social rights (Cambridge: Cambridge University Press).

Kmiec, Kennan (2004) The origins and current meanings of "judicial activism". California Law Review 92(5), pp. 1441-77. 
This is an Accepted Manuscript of an article published by Taylor \& Francis in Asian Studies Review on 3 April 2015, available online:

http://www.tandfonline.com/doi/full/10.1080/10357823.2015.1024099

McCann, Michael (1994) Rights at work (Chicago: University of Chicago Press).

Menon, Nivedita (2004) Recovering subversion: Feminist politics beyond the law (Chicago: University of Illinois Press).

O'Connell, Paul (2007) On reconciling irreconcilables: Neo-liberal globalisation and human rights. Human Rights Law Review 7(3), pp. 483-509.

Odinkalu, Chidi (2008) The impact of economic and social rights in Nigeria: An assessment of the legal framework for implementing education and health as human rights, in Varun Gauri and Daniel Brinks (eds), Courting social justice: Judicial enforcement of social and economic rights in the developing world, pp. 183-223 (Cambridge: Cambridge University Press).

Rajagopal, Balakrishnan (2012) Limits of law in counter-hegemonic globalization: The Indian Supreme Court and the Narmada Valley struggle (New Delhi: Centre for the Study of Law and Governance, Jawaharlal Nehru University).

Rosenberg, Gerald (1991) The hollow hope: Can courts bring about social change? (Chicago: University of Chicago Press).

Rosser, Andrew (2015) Law and the realisation of human rights: Insights from Indonesia's education sector. Asian Studies Review 39(2), pp. 
This is an Accepted Manuscript of an article published by Taylor \& Francis in Asian Studies Review on 3 April 2015, available online:

http://www.tandfonline.com/doi/full/10.1080/10357823.2015.1024099

Rosser, Andrew and Jayne Curnow (2014) Legal mobilisation and justice: Insights from the Constitutional Court case on international standard schools in Indonesia. The Asia-Pacific Journal of Anthropology 15(4), pp. 302-318 .

Scheingold, Stuart (1974) The politics of rights: Lawyers, public policy, and political change, $2^{\text {nd }}$ edition (Ann Arbor: University of Michigan Press).

Silverstein, Helena (2003) The symbolic life of law: The instrumental and the constitutive in Scheingold's The politics of rights. International Journal for the Semiotics of Law 16(4), pp. 407-23.

Skaar, Elin and Jose Van Dúnem (2006) Courts under construction in Angola: What can they do for the poor? Chr. Michelsen Institute Working Paper 20/2006.

Sklair, Leslie (2002) Globalization: Capitalism and its alternatives (Oxford: Blackwell Publishing).

Smith, Stephen and Bob McMullan (2009) Budget: Australia's international development assistance program: A good international citizen (Canberra: Commonwealth of Australia).

United Nations Development Programme (2006) Applying a human rights-based approach to development cooperation and programming: A UNDP capacity development resource (Geneva: United Nations Development Programme). 
This is an Accepted Manuscript of an article published by Taylor \& Francis in Asian Studies Review on 3 April 2015, available online:

http://www.tandfonline.com/doi/full/10.1080/10357823.2015.1024099

Vanhala, Lisa (2011) Making rights a reality? Disability rights activists and legal mobilization (New York: Cambridge University Press).

Wilson, Bruce (2009) Institutional reform and rights revolutions in Latin America: The cases of Costa Rica and Columbia. Journal of Politics in Latin America 1(2), pp. 59-85.

Wilson, Bruce (2011) The causes and consequences of health rights litigation in Costa Rica, in Alicia Yamin and Siri Gloppen (eds), Litigating health rights: Can courts bring more justice to health?, pp. 132-54 (Cambridge, MA: Harvard University Press).

Wilson, Bruce and Juan Cordero (2006) Legal opportunity structures and social movements: The effects of institutional change on Costa Rican politics. Comparative Political Studies 39(3), pp. 325-51.

World Bank (1998) Development and human rights: The role of the World Bank (Washington, DC: World Bank).

Yamin, Alicia and Siri Gloppen, eds. Litigating health rights: Can courts bring more justice to health? (Cambridge, MA: Harvard University Press).

\footnotetext{
Notes

${ }^{1}$ Epp (1998) has defined "rights revolutions" as involving judicial attention to new rights, judicial support for these rights, and judicial implementation of these rights.

${ }^{2}$ Elias, personal communication.
} 


\section{University Library}

\section{- M M I N E R VA A gateway to Melbourne's research publications}

Minerva Access is the Institutional Repository of The University of Melbourne

Author/s:

Rosser, A

Title:

Realising Rights in Low Quality Democracies: Instructive Asian Cases

Date:

2015-04-03

Citation:

Rosser, A. (2015). Realising Rights in Low Quality Democracies: Instructive Asian Cases. ASIAN STUDIES REVIEW, 39 (2), pp.180-193. https:// doi.org/10.1080/10357823.2015.1024099.

Persistent Link:

http://hdl.handle.net/11343/127208 